UDC 811.163.41'242

UDC 811.163.41'367.625

https://doi.org/10.18485/ms_zmsfil.2021.64.2.7

Изворни научни рад

Nina Ilić

Sabina Halupka-Rešetar

\title{
VERB PRODUCTION AT DIFFERENT STAGES OF FIRST LANGUAGE ACQUISITION: FOCUS ON SERBIAN*
}

This paper examines the production of verbs with different argument structure (unergative, unaccusative, anti-causative, transitive and ditransitive verbs) at different stages of first language acquisition, with the aim of contributing to the ongoing nature-nurture debate. Twenty verbs were tested (four verbs of each type). A total of eighteen subjects belonging to six age groups (18-21, 23-25, 31-33, 35-38, 39-43 and 48-52 months - three participants each) took part in this pilot research. Visual stimuli were used in a verb elicitation task. Though the sample was small, significant among-group differences were noted. The results show that children at a lower stage of language development have more difficulty producing verbs with a complex argument structure. The acquisition of verbs starts with transitive and unergative verbs, followed by unaccusative verbs. The production of ditransitive and anti-causative verbs is delayed.

Key words: verb production, argument structure, first language acquisition, early development of syntax, nativism.

У раду се испитује продукција глагола различите аргументске структуре (неергативни, неакузативни, антикаузативни, транзитивни и дитранзитивни глаголи) у различитим фазама усвајања матерњег језика, са циљем да се на тај начин допринесе дебати о томе да ли је усвајање језика омогућено генетским наслеђем или је оно резултат спољних утицаја (изложености и учења). Тестирано је двадесет глагола, по четири свакога типа. Укупно је тестирано осамнаест испитаника који припадају следећим старосним групама: $18-21,23-25,31-33,35-38,39-43$ и 48-52 месеци (по троје у свакој групи). У задатку елицитиране продукције користили смо визуелни материјал. Иако је узорак испитаника био мали, забележене су значајне разлике међу групама. Резултати указују на то да деца на нижем ступњу језичког развоја теже продукују глаголе комплексне аргументске структуре. Усвајање глагола почиње усвајањем транзитивних и неергативних глагола, потом се усвајају неакузативни глаголи, док усвајање дитранзитивних и антикаузативних глагола касни.

Кључне речи: продукција глагола, аргументска структура, усвајање матерњег језика, рани развој синтаксе, нативизам.

1. InTRODUCTION. The acquisition of the argument structure of verbs within the process of first language acquisition (LA) has raised a lot of interest. The results of cross-linguistic research into the acquisition of verbs with different argument structure are not conclusive. While some studies present results which support the nativist theory of language acquisition (PINKER 1984; 1989; GleITMAN 1990; SNyder et al. 1995; Lorusso et al. 2005; LeE - NAigles 2005; CostA - FriedmanN 2012), others show that the acquisition of verbs can be explained within the con-

${ }^{*}$ The paper is the result of research conducted within project no. 178002 Languages and cultures in time and space funded by the Ministry of Science and Technological Development of the Republic of Serbia. 
structivist, usage-based theory (Braine 1976; MacWhinney 1978; Bowerman 1990; Lieven et al. 1997; Ninio 1999; Childers - Tomasello 2001; Tomasello 2003; LIEVEN 2008). This paper explores the production of verbs of different syntactic complexity by Serbian-speaking children at an early age and thus tries to make a contribution to the ongoing nature-nurture debate.

\section{THeORETICAL BACKGROUND}

2.1. NATIVISM. One of the main approaches to the theory of language acquisition was outlined by Сном⿰ку $(1975 ; 1981 ; 1986)$ within the generative theory of Universal Grammar (UG). According to this theory, all human beings are endowed with the knowledge of UG. UG is the genetically transmitted language faculty, which plays an essential role in children's acquisition of their native language, guiding them in the process of analyzing linguistic units.

Nativism has spurred a wide range of research into the acquisition of verbs. However, the results of the existing research appear to be inconclusive. Whereas some researchers have claimed that children's linguistic knowledge needs a certain amount of time to mature and to become native-like (which is in contrast with PINKER's $(1984 ; 1989)$ ideas on canonical linking), others have argued that children possess early knowledge of argument structure. While the former approach supports the Maturation Hypothesis (BORER - WEXLER 1987; BABYONYSHEV et al. 2001), the latter one supports the Continuity Hypothesis (SNYDER et al. 1995; Lorusso et al. 2005; Costa - Friedmann 2012).

2.2. Cognitive Linguistics. A different account of first language acquisition, supporting the "nurture" side of the nature-nurture debate, has gained a lot of supporters recently. The supporters of this theory (ToMASELLO 2003; LIEVEN 2008) depart from the idea of the existence of an inborn mechanism for the acquisition of language and believe that language rules are learnt inductively. They reject the nativist Continuity Hypothesis and argue in favor of the Discontinuity Hypothesis. One of the main representatives of the usage-based theory within the cognitive linguistics framework, ToMASELlo (2003) argues that experience is crucial for acquisition. Moreover, he claims that acquisition happens through general cognitive processes and interpersonal capacities. He specifies four processes that are crucial for LA, namely intention-reading, relevance assumptions, role reversal imitation, and pattern-finding. Many studies (LIEVEN et al. 1997; CHILDERS - TOMASELLO 2001; LIEVEN 2008, to name but a few) have shown that young children's language revolves around concrete exemplars, and not abstract grammatical categories.

2.3. Early verbs in Serbian - a usage-Based account. Recently, AnĐelković (2012) studied the production of verbs of Serbian-speaking children at early stages of language acquisition (18-48 months). She analyzed the early spontaneous production of eight children (four boys and four girls) given in the Serbian Electronic Corpus of Children's Early Language (ANĐELKOvić et al. 2001), which is standardized according to the CHILDES system. She provided an inventory of early verbs at the age of eighteen months and analyzed the development of argument structure on the basis of three verbs of high frequency (dati 'give', imati existential 'have' and imati transitive 'have') occurring in the period between 18 and 28 months of age. 
It is important to mention that ANĐELKović (2012) found verbs which are non-canonical (imati existential 'have') and verbs with three arguments (dati 'give') at the earliest age. Her analysis of the frequency of existential and transitive ima$t i$ 'have' showed that these two verbs are quite equally balanced in children's early production. Thus, she brought into question PINKER's (1984; 1989) Canonical Linking Hypothesis, as well as the nativist assumption that the verbs with the least number of arguments are acquired first (FISHER et al. 1994). Moreover, by categorizing existential imati 'have' as perceptively unavailable, ANĐELKOvić (2012) provided a counter-argument to the claim that the acquisition of conceptually more difficult and perceptively unavailable verbs is delayed (HUTTENLOCHER et al. 1983). However, we do not agree with ANĐELKOviĆ's (2012) claim that the existential imati 'have' is perceptively unavailable, since it is often used to refer to something that the child sees in the extra-linguistic reality.

Regarding the development of the argument structure of the verb dati 'give', AnĐELKOVIĆ (2012) found that the use of the "frozen" imperative $d a(j)$ 'give' dominated in production at the earliest stage. It was only at later stages that the children slowly and gradually began combining this verb with its arguments. However, what AnĐeLrović (2012) failed to mention is that this form is rather problematic in Serbian, because it shows syncretism with the particle daj ('come on'), which increases its frequency in child-directed speech. Moreover, the children often used hyper-generalized meanings of the verb dati 'give' (in situations as different as giving, taking or asking for something), which shows that they had still not acquired the structure and meaning of this verb completely at that point of acquisition.

Taking into consideration both the nativist and the usage-based account, as well as the studies conducted within these two frameworks, we expect that the present research into the production of verbs in a cross-sectional study will tell us more about the argument structure that is available to children at different stages of acquisition. Since ANĐELKOvić (2012) found some unaccusative verbs produced at the earliest stage (18 months), we expect that the results of the present research could replicate this finding, especially because unergative and unaccusative verbs take only one argument and are therefore syntactically not very complex. Moreover, many nativist studies have provided evidence that children use unaccusative verbs from the earliest age (SNYDER ET AL. 1995; LoRUSSO et al. 2005; COSTA - Friedmann 2012). We also expect that the largest number of verbs produced by the youngest participants will be transitive verbs. We do not expect, however, that children will produce ditransitive and anti-causative verbs correctly at the earliest stage of acquisition. Therefore, we are more prone to accept the nativist approach. Yet, if these initial hypotheses prove false and if ditransitive and anti-causative verbs are produced at the earliest stages of language acquisition, this will provide evidence against nativism, i.e. in favor of the usage-based account.

\section{The PILOT STUDY}

3.1. SubJeCTs. The participants in the experiment were 18 monolingual Serbian-speaking children ranging in age from 18 to 52 months. The children belonged to six age groups (three participants in each group): 18-21 months, 23-24 months, 31-33 months, 35-36 months, 39-44 months, and 48-52 months of age. The mean 
ages per group were $20,23.67,32,35.67,41$ and 50.33 months, respectively. There were ten boys and eight girls tested. None of the children selected had any language impairment, learning disability, or visual or hearing loss. Their kindergarten teachers provided all the children's relevant information (the child's birth date, information about their mother tongue and health status). The study was approved by the Ethics Committee at the Faculty of Philosophy, University of Novi Sad. The children were tested in March 2015, in 'Mrvica' kindergarten, 'Radosno detinjstvo' preschool facility in Novi Sad.

3.2. Method AND STIMULI. The participants performed a verb elicitation task. For this purpose, twenty verbs were chosen. The experiment consisted of two parts in which different stimuli were used. Two types of stimuli were chosen in order to check if one methodology was more sensitive to capturing the patterns of response. Puppets and toys were used to elicit verbs in the first part of the experiment, while colored drawings were used in the second part (see details below). Five verb types were tested in each part of the experiment: unergative, simple transitive, unaccusative, ditransitive and anti-causative verbs. The interviewer's descriptions and questions were prepared in advance in order to prevent using the words that were being elicited from the children.

In the first part of the experiment, we tested three unergative verbs (lajati 'bark', spavati 'sleep', skakati 'jump'), three simple transitive verbs (jesti 'eat', piti 'drink', pevati 'sing'), two unaccusative verbs (pasti 'fall', svetleti 'flash'), two ditransitive verbs (baciti 'throw', dati 'give') and two anti-causative verbs (zatvoriti se 'close', ugasiti se 'turn off'). Thus, there was a total of twelve verbs tested in this part. An example of a toy used as a stimulus (for the verb lajati 'bark') is given in Figure 1.

Figure 1. Toy stimulus.

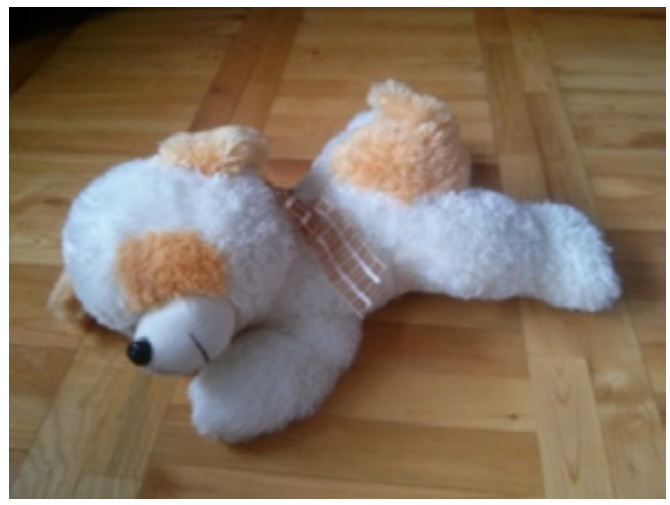

In the second part of the experiment, one unergative verb (trčati 'run'), one simple transitive verb (voziti 'drive'), two unaccusative verbs (imati existential 'have', pući 'pop/burst'), two ditransitive verbs (kupiti 'buy', staviti 'put') and two anti-causative verbs (otvoriti se 'open', pokvariti se 'break') were tested, i.e. eight verbs in total. The verbs were distributed in this way because it was easier to present some events with toys (e.g. lajati 'bark'), whereas others were depicted 
more easily with drawings (e.g. trčati 'run'). An example of a drawing used as a stimulus (for the verb trčati 'run') is given in Figure 2.

Every interview was transcribed following the rules of the CHILDES transcription system. Answers were coded as 'target' when the children produced the target verb, or as 'non-target,' when they did not give an answer or produced a non-target word. Self-corrections were allowed. Closely synonymous verbs, which belong to the same verb type, and therefore have the same number of arguments, were also coded as 'target'. Alternative answers were noted.

Figure 2. Drawing stimulus.

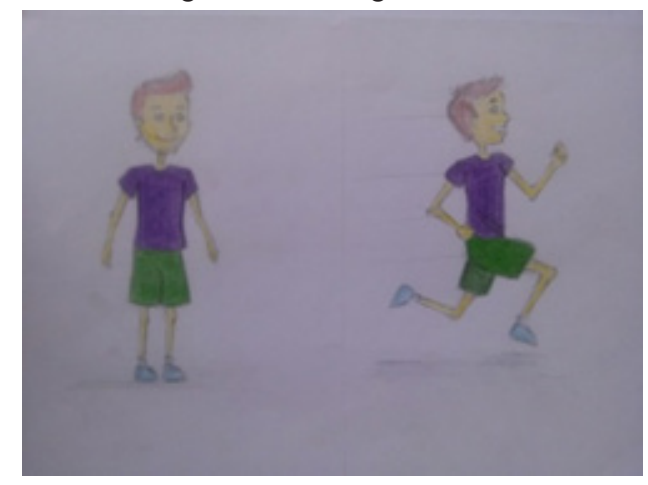

3.3. Procedure. Parental consent forms were obtained prior to the testing for every child. Parents also gave their permission for the sessions to be audio-taped using a Dictaphone/voice recorder. Fifteen participants were tested in single sessions that lasted up to 10 minutes. The remaining three participants (aged 1;6 months; $1 ; 9$ months and $1 ; 11$ months) were tested in 3 sessions each, due to their inability to concentrate on the task for the required period of time.

Each child was tested individually, in one of the rooms provided by the staff at the kindergarten. The only people present were the interviewer, the interviewee and occasionally the kindergarten teacher, which was inevitable, since some children were reluctant to participate without their teacher accompanying them. Occasional interruptions were unavoidable.

First, the interviewer was introduced to the child who was going to be tested. They spent some time together before the testing began. The child was introduced to the puppets and told that he/she would see and be asked to say what the puppets were doing. The procedure consisted of the experimenter describing situations, ${ }^{1}$ one by one. After the situation was described, the experimenter would ask the participant what the puppet was doing. An example of a situation that was presented to the children is given below, followed by the expected answer:

"Interviewer: Here's a dog. Hello, dog. He is very tired, so we now need to put a blanket over him. And now the dog... (Imitation of snoring) What is he doing now? Interviewee: He is sleeping.

Interviewer: Yes, very good."

\footnotetext{
1 'Situation' is used as a term for actions, states, and occurrences (COMRIE 1976).
} 
The second part of the interview consisted of questions related to drawings. Each visual stimulus included two related pictures presenting a single situation. The interviewer first described one picture. Then, the child was expected to look at the other picture and the interviewer would ask him/her what the person in the picture was doing in the case of animate arguments of the verb or what had happened in the case of inanimate ones. An example of one such situation is the following:

"Interviewer: Oh, look at this box. What happened to it in the second picture?

Interviewee: It opened.

Interviewer: Good."

The interviewer would give some positively neutral feedback and make a short break between two situations. If the child did not respond, the interviewer would repeat the question. If the child remained silent, the interviewer would go on to the next question.

\section{RESULTS}

4.1. Unergative Verbs. ${ }^{2}$ As far as unergative verbs are concerned, they were produced in every group tested. Group 1 produced four target verbs. The verb trčati 'run' was produced twice, and the verbs lajati 'bark' and spavati 'sleep' were produced once. As it can be seen in Figure 3, the number of verbs produced doubled in Group 2. The verb spavati 'sleep' was produced by all the participants, and the verbs skakati 'jump' and trčati 'run' were produced twice each.

The production was very high for the remaining four groups. In Group 3, only the verb trčati 'run' was not produced by all the participants, thus resulting in eleven correctly produced verbs. In Group 4, the production of unergative verbs was lower than the production of unergative verbs in Group 3, because the verb lajati 'bark' was produced only once. The production in Group 5 was exactly the same as in Group 3. Finally, in Group 6, all the target verbs were produced by all the participants.

Figure 3. Unergative verb production.

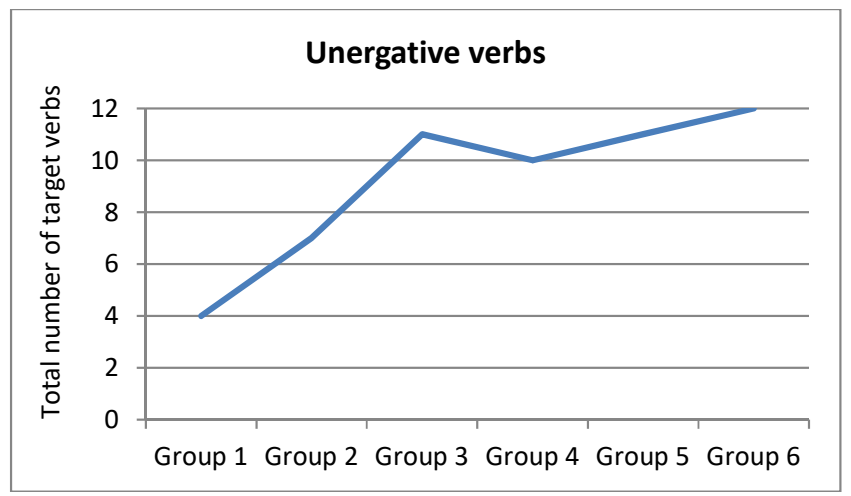

${ }^{2}$ For a detailed overview of the production of individual verbs and verb types per age group of participants see the tables in the Appendix. 
4.2. TRAnsitive Verbs. Transitive verbs were produced from the youngest age tested. As expected, the production of transitive verbs was more successful than the production of any other verb type tested. Group 1 produced five of the 12 target verbs. The verbs jesti 'eat' and voziti 'drive' were produced twice. The production was not as successful for the verb piti 'drink', which was produced only once.

There was a great increase in the production of transitive verbs in Group 2, as shown in Figure 4. Not only did the trend of a better production of transitive verbs than any other type of verbs continue in this group, but the participants' performance was remarkable. There were ten target verbs produced. The verbs jesti 'eat', piti 'drink', and voziti 'drive' were produced by all the participants. Whereas there were no correct answers for the verb pevati 'sing' in the previous group, there was one correct answer in this group. In the remaining groups, the participants had no difficulty producing this type of verb. In Group 3, only the verb pevati 'sing' was not produced by one of the participants. Transitive verbs were the only type of verb that reached maximum production in three of the six groups tested - Groups 4, 5 and 6.

Figure 4. Transitive verb production.

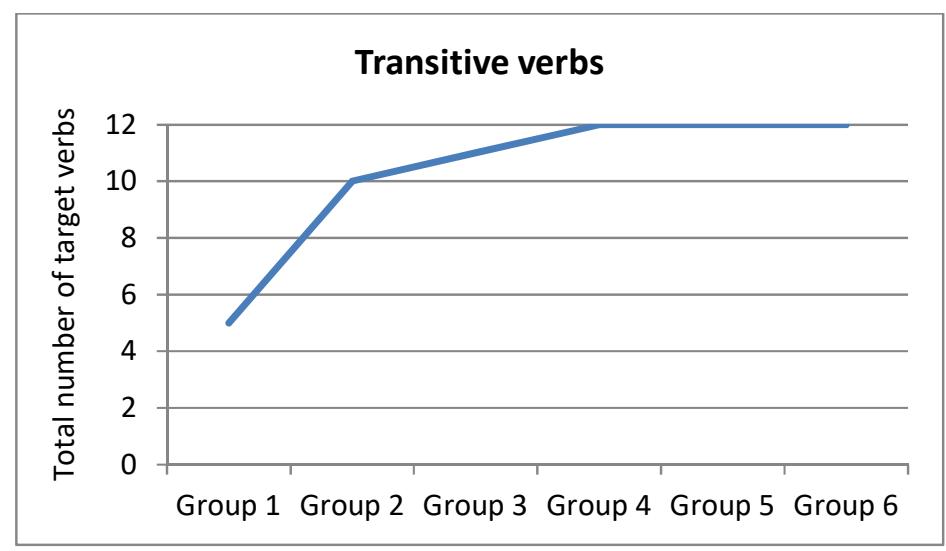

4.3. UnACCUSATIVE VERBS. As expected, the production of unaccusative verbs was not as successful as the production of transitive and unergative verbs in Group 1. The verbs pasti 'fall', pući 'pop/burst', and imati 'have' were each produced once. There were no responses for the verb svetleti 'flash'. Unlike the production of unergative verbs, the production of unaccusative verbs did not double in Group 2, as can be seen in Figure 5. It was again considerably lower than the production of unergative and transitive verbs. The only verb for which the production was higher was the existential verb imati 'have', which was produced by all the participants. The verb pasti 'fall' was produced only once. There were no responses for the verbs svetleti 'flash' and puci 'pop/burst'.

However, the production of unaccusative verbs was rather high in Groups 3 , 4, 5 and 6, although it was somewhat lower in Group 4, as shown in the figure below. In Group 3, the verb svetleti 'flash' was produced by two participants, 
whereas the production of all the remaining target verbs was flawless. The reason for the lower production in Group 4 is that the verb pući 'pop/burst' was produced only once. However, this verb was replaced with the verb probušiti se 'pierce'. This verb corresponds semantically to the situation described, but it is syntactically more complex and could therefore not be coded as 'target'. In addition, the verb pasti 'fall' was not produced by one participant, who replaced it with another unaccusative verb, nestati 'disappear'. Similar to the situation observed in Group 4, one participant replaced the verb pući 'pop/burst' with the anti-causative verb pocepati se 'tear' in Group 5. Finally, in Group 6, only the production of the verb imati 'have' failed to reach maximum production.

Figure 5. Unaccusative verb production.

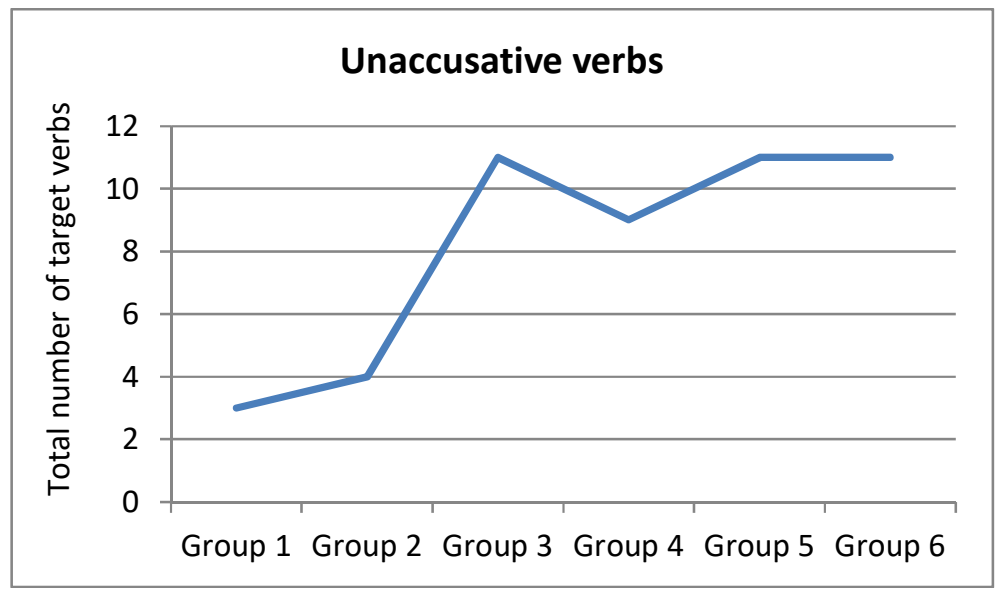

4.4. Ditransitive Verbs. Figure 6 shows that the production of ditransitive verbs was delayed. Group 1 did not produce any of the target ditransitive verbs. However, some children produced the ditransitive verbs dati 'give' and baciti 'throw', even though these were not counted as target answers. The reason why these verbs were not coded as 'target' is that children either used them immediately after hearing that word from the interviewer (not as part of a question that should elicit that verb) or they used an incorrect form of the verb. The imperative form of the verb $d a j$ 'give.2p.sg.imp.' instead of the target forms daje (3.p.sg.pres.) or dala (3.p.sg.past.fem) was produced. Previous studies have shown that this form of the verb 'give' without arguments is the first one to appear in child language (ARMON-LOTEM 1997).

While Group 1 did not produce any ditransitive verbs, Group 2 produced two ditransitive verbs: baciti 'throw' and kupiti 'buy'. In Group 3, the production of ditransitive verbs increased, but it was still quite low. The verbs baciti 'throw' and staviti 'put' were produced by two participants, whereas the verb kupiti 'buy' was produced only once. The verb dati 'give' was still not produced. The number of ditransitive verbs sharply increased in Group 4, after which it remained quite constant. The production of ditransitive verbs was even higher than the production 
of unergative, unaccusative and anti-causative verbs in this group. Except for the target verb staviti 'put', which was produced by two participants, the production was flawless. The production of ditransitive verbs was as successful as the production of unergative and unaccusative verbs in Group 5, but this time the verb baciti 'throw' was not produced by one of the participants. Finally, in Group 6, all the target verbs were produced.

Figure 6. Ditransitive verb production.

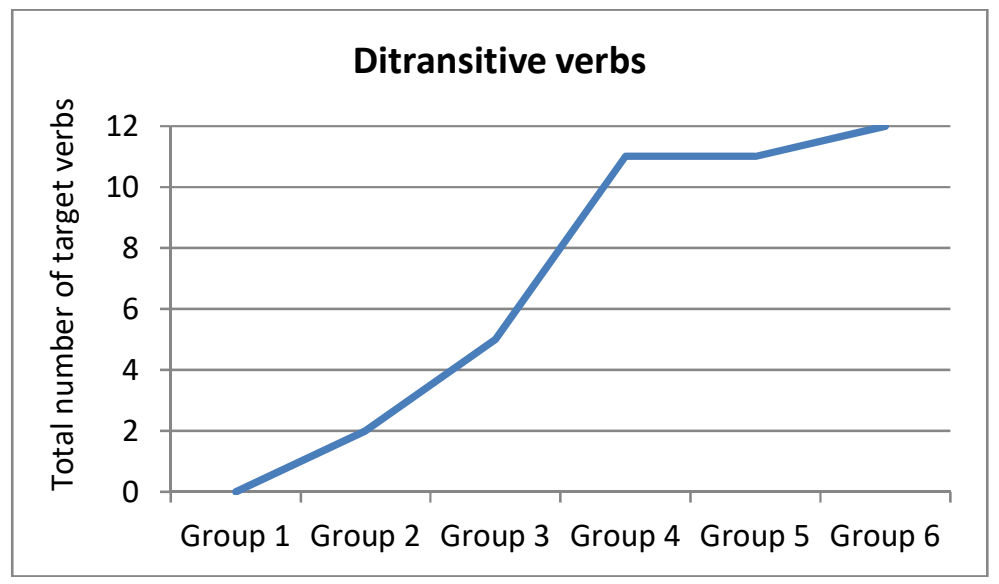

4.5. Anti-Causative Verbs. The production of anti-causative verbs also proved to be delayed as no verbs of this type were produced by the youngest two groups of participants at all. As shown in Figure 7, their production rocketed in Group 3, after which it only slowly increased. In Group 3, it was even more successful than the production of ditransitive verbs. The verb zatvoriti se 'close' was produced by all the participants. The verbs otvoriti se 'open' and pokvariti se 'break' were produced twice each. The verb ugasiti se 'turn off' proved to be more difficult as it was produced only once. In Group 4, the verbs zatvoriti se 'close' and otvoriti $s e$ 'open' were produced by all the participants, whereas the verbs ugasiti se 'turn off' and pokvariti se 'break' were produced twice each.

In Group 5, the production was a bit lower than the production in Group 4. Only the verb ugasiti se 'turn off' was produced by all the participants. The verbs zatvoriti se 'close', pokvariti se 'break' and otvoriti se 'open' were produced by two participants. In Group 6, the production of anti-causative verbs was somewhat lower than the production of other verb types. The verbs ugasiti se 'turn off' and otvoriti se 'open' were produced by all the participants. The verbs zatvoriti se 'close' and pokvariti se 'break' were produced by two participants. What must be pointed out though is that one participant actually produced the passive forms of the verbs zatvoriti se 'close' and ugasiti se 'turn off'. Since passive verbs also have one argument, which is a theme, these answers were coded as 'target'. 
Figure 7. Anti-causative verb production.

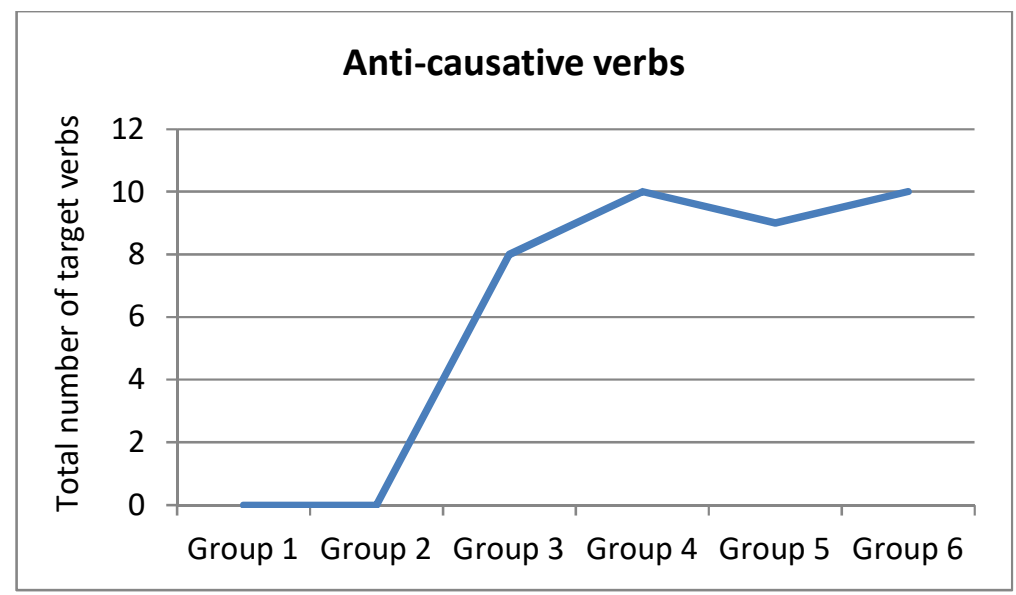

\section{DISCUSSION}

5.1. Limitations of THE STUDY. The results of this cross-sectional research indicate that children acquire syntactically less complex verbs first. What needs to be said though is that the number of participants in the study was rather limited, which is also the reason why a statistical analysis could not be conducted. Our initial intention was to test at least five children in each group. However, this was impossible due to not having obtained enough parental consent forms. Therefore, the results of the research should be taken with caution at least until a study with a larger number of participants is conducted. Another drawback of the research is the fact that the frequencies of the target verbs in child language could not be explored in detail, because there is no frequency dictionary of child language at early stages of language acquisition for Serbian. However, we checked the verbs in Anđelković's (2012) inventory of verbs produced at the age of 18 months (which was the earliest age tested in this study), excerpted from CHILDES. All transitive and ditransitive verbs and the majority of unergative and unaccusative verbs that were used as stimuli in the present pilot study can be found there. The only verb type that was not found at this age were anti-causative verbs, although the transitive forms of otvoriti 'open' and zatvoriti 'close' were found as well. Due to the limited number of children whose transcripts are found in the corpus, the frequencies of the verbs were understandably rather small.

5.2. IMPLiCATIONS FOR THE NATURE-NURTURE DEBATE. The major finding of this study is that syntactically more complex verbs seem to be acquired after less complex ones, which is in line with PINKER's Canonical Linking Hypothesis (1984, 1989). This especially holds true for ditransitive and anti-causative verbs. Reflecting on the debate about whether unaccusative verbs are learnt early or whether there is a maturational delay with A-chains, it is important to stress that the results of the present study do not support the maturational delay approach, since unaccusative verbs were produced even by the youngest participants. 
The observed difficulty with anti-causative verbs cannot be attributed to the children's problem with the formation of A-chains, since even the youngest participants produced unaccusative verbs. It may lie in the difficulty of linking the surface subject with an underlying object position, as SNYDER - Hyams (2008) suggested for passive constructions. Alternatively, it may be the case that the external argument of anti-causatives is removed before the remaining argument is merged internally (REINHART - SILONI 2005), which may pose an additional problem for children, who prefer the transitive variants of anti-causative verbs.

Hypothesizing possible reasons why the acquisition of ditransitive verbs is delayed, apart from the Canonical Sentence Strategy Hypothesis (BEVER 1970), it is interesting to discuss some of the conclusions reached in relation to intentional verbs. In their study, HUTTENLOCHER et al. (1983) found that children (22-30 months old) could produce and comprehend both verbs of motion and intentional verbs. Yet, they produced and understood both types of verbs only when they themselves were the agents of the target actions. When they were supposed to identify actions of other people, they could only identify movement. HUTTENLOCHER et al. (1983) suggested that that is because children are unable to identify the intentions of other people. This may also be one of the reasons why the ditransitive verbs tested were more problematic for the participants than other types of verbs.

It is of paramount importance to mention that the participants used adequate tense morphology on the verbs from the earliest age. This indicates that they can recognize verbs as members of a coherent syntactic category, different from that of nouns (verbs are always inflected for person and tense in Serbian, which is how they differ from nouns), which in turn supports the nativist approach. It also speaks against the usage-based account, which suggests that learning is item-based and that very young children are unable to make generalizations. The consistent use of the third person singular verb form by the participants in this study provides evidence that children are able to generalize from the earliest age.

6. ConClusion. In brief, the results of the present study, which was aimed at examining the production of verbs with different argument structures (unergative, unaccusative, anti-causative, transitive and ditransitive verbs) at different stages of first language acquisition and thereby contributing to the nature-nurture debate, show that children at a lower stage of language acquisition have more difficulty producing verbs with a complex argument structure, either those with a third argument or those which involve a complex syntactic process of derivation from a transitive verb. The acquisition of verbs starts with transitive and unergative verbs, followed by unaccusative verbs, while the production of ditransitive and anti-causative verbs is delayed.

In order to gain further insight into the individual development of children, a longitudinal study should be conducted in an attempt to increase our understanding of the nature of verb acquisition. Collecting an extensive corpus of child language in Serbian would be helpful in that sense, which is why that should be one of the primary goals of future research into first language acquisition in Serbian. 


\section{APPENDIX: VERB PRODUCTION PER VERB TYPE} AND AGE GROUP OF PARTICIPANTS

\begin{tabular}{|c|c|c|c|c|c|}
\cline { 2 - 6 } \multicolumn{1}{c|}{} & \multicolumn{5}{c|}{ UNERGATIVE VERBS } \\
\hline $\begin{array}{c}\text { Target verbs/ } \\
\text { Groups }\end{array}$ & trčati 'run' & lajati 'bark' & $\begin{array}{c}\text { spavati } \\
\text { 'sleep' }\end{array}$ & $\begin{array}{c}\text { skakati } \\
\text { 'jump' }\end{array}$ & $\begin{array}{c}\text { Total number of } \\
\text { verbs produced }\end{array}$ \\
\hline Group 1 & 2 & 1 & 1 & 0 & 4 \\
\hline Group 2 & 2 & 0 & 3 & 2 & 7 \\
\hline Group 3 & 2 & 3 & 3 & 3 & 11 \\
\hline Group 4 & 3 & 1 & 3 & 3 & 10 \\
\hline Group 5 & 2 & 3 & 3 & 3 & 11 \\
\hline Group 6 & 3 & 3 & 3 & 3 & 12 \\
\hline
\end{tabular}

\begin{tabular}{|c|c|c|c|c|c|}
\cline { 2 - 6 } \multicolumn{1}{c|}{} & \multicolumn{5}{c|}{ TRANSITIVE VERBS } \\
\hline $\begin{array}{c}\text { Target verbs/ } \\
\text { Groups }\end{array}$ & $\begin{array}{c}\text { jesti } \\
\text { 'eat' }\end{array}$ & $\begin{array}{c}\text { piti } \\
\text { 'drink' }\end{array}$ & pevati 'sing' & $\begin{array}{c}\text { voziti } \\
\text { 'drive' }\end{array}$ & $\begin{array}{c}\text { Total number of } \\
\text { verbs produced }\end{array}$ \\
\hline Group 1 & 2 & 1 & 0 & 2 & 5 \\
\hline Group 2 & 3 & 3 & 1 & 3 & 10 \\
\hline Group 3 & 3 & 3 & 2 & 3 & 11 \\
\hline Group 4 & 3 & 3 & 3 & 3 & 12 \\
\hline Group 5 & 3 & 3 & 3 & 3 & 12 \\
\hline Group 6 & 3 & 3 & 3 & 3 & 12 \\
\hline
\end{tabular}

\begin{tabular}{|c|c|c|c|c|c|}
\cline { 2 - 6 } \multicolumn{1}{c|}{} & \multicolumn{5}{c|}{ UNACCUSATIVE VERBS } \\
\hline $\begin{array}{c}\text { Target verbs/ } \\
\text { Groups }\end{array}$ & pasti 'fall' & $\begin{array}{c}\text { svetleti } \\
\text { 'flash' }\end{array}$ & $\begin{array}{c}\text { imati } \\
\text { 'have' }\end{array}$ & $\begin{array}{c}\text { pući } \\
\text { 'pop' }\end{array}$ & $\begin{array}{c}\text { Total number of } \\
\text { verbs produced }\end{array}$ \\
\hline Group 1 & 1 & 0 & 1 & 1 & 3 \\
\hline Group 2 & 1 & 0 & 3 & 0 & 4 \\
\hline Group 3 & 3 & 2 & 3 & 3 & 11 \\
\hline Group 4 & 2 & 3 & 3 & 1 & 9 \\
\hline Group 5 & 3 & 3 & 3 & 2 & 11 \\
\hline Group 6 & 3 & 3 & 2 & 3 & 11 \\
\hline
\end{tabular}

\begin{tabular}{|c|c|c|c|c|c|}
\cline { 2 - 6 } \multicolumn{1}{c|}{} & \multicolumn{5}{c|}{ DITRANSITIVE VERBS } \\
\hline $\begin{array}{c}\text { Target verbs/ } \\
\text { Groups }\end{array}$ & dati 'give' & baciti 'throw' & kupiti 'buy' & staviti 'put' & $\begin{array}{c}\text { Total number of } \\
\text { verbs produced }\end{array}$ \\
\hline Group 1 & 0 & 0 & 0 & 0 & 0 \\
\hline Group 2 & 0 & 1 & 1 & 0 & 2 \\
\hline Group 3 & 0 & 2 & 1 & 2 & 5 \\
\hline Group 4 & 3 & 3 & 3 & 2 & 11 \\
\hline Group 5 & 3 & 2 & 3 & 3 & 11 \\
\hline Group 6 & 3 & 3 & 3 & 3 & 12 \\
\hline
\end{tabular}




\begin{tabular}{|c|c|c|c|c|c|}
\cline { 2 - 6 } \multicolumn{1}{c|}{} & \multicolumn{5}{c|}{ ANTI-CAUSATIVE VERBS } \\
\hline $\begin{array}{c}\text { Target verbs/ } \\
\text { Groups }\end{array}$ & $\begin{array}{c}\text { zatvoriti se } \\
\text { 'close' }\end{array}$ & $\begin{array}{c}\text { ugasiti se } \\
\text { 'turn off' }\end{array}$ & $\begin{array}{c}\text { otvoriti se } \\
\text { 'open' }\end{array}$ & $\begin{array}{c}\text { pokvariti se } \\
\text { 'break' }\end{array}$ & $\begin{array}{c}\text { Total number of } \\
\text { verbs produced }\end{array}$ \\
\hline Group 1 & 0 & 0 & 0 & 0 & 0 \\
\hline Group 2 & 0 & 0 & 0 & 0 & 0 \\
\hline Group 3 & 3 & 1 & 2 & 2 & 8 \\
\hline Group 4 & 3 & 2 & 3 & 2 & 10 \\
\hline Group 5 & 2 & 3 & 2 & 2 & 9 \\
\hline Group 6 & 2 & 3 & 3 & 2 & 10 \\
\hline
\end{tabular}

\section{REFERENCES}

ANĐELKović, Darinka. Glagoli i glagolske dopune u razvoju dečijeg govora. Neobjavljena doktorska disertacija, Univerzitet u Beogradu, 2012.

AnĐelKović, Darinka, Nada ŠEva, Jasmina Moskovljević. Srpski elektronski korpus ranog dečijeg govora. Beograd, Srbija: Laboratorija za eskperimentalnu psihologiju, Filozofski fakultet u Beogradu; Katedra za opštu lingvistiku, Filološki fakultet u Beogradu, 2001.

Armon-Lotem, Sharon. A Parametric Approach to Functional Heads and the Acquisition of Hebrew. Doctoral dissertation, Tel-Aviv University, 1997.

Babyonyshev, Maria, Ronald Fein, Jennifer Ganger, David Pesetsky, Kenneth Wexler. The Maturation of Grammatical Principles: Evidence from Russian Unaccusatives. Linguistic Inquiry 32 (2001): 1-44.

Bever, Thomas G. The Cognitive Basis for Linguistic Structures. John R. Hayes (eds.). Cognition and the Development of Language. New York: Wiley, 1970, 279-362.

Borer, Hagit, Kenneth WexLer. The Maturation of Syntax. Thomas Roeper, Edwin Williams (eds.). Parameter Setting. Dordrecht: Reidel, 1987, 23-172.

Bowerman, Misha. Mapping Thematic Roles onto Syntactic Functions: Are Children Helped by Innate Linking Rules? Linguistics 28 (1990): 1291-1330.

Braine, Martin. Children's First Word Combinations. Monographs of the Society for Research in Child Development 41 (1976): 1-104.

Childers, Jane, Michael Tomasello. The Role of Pronouns in Young Children's Acquisition of the English Transitive Construction. Developmental Psychology 37 (2001): 739-748.

Сномкку, Noam. The Logical Structure of Linguistic Theory. New York: Plenum, 1975.

Сномкку, Noam. Lectures on Government and Binding. Berlin: Mouton de Gruyter, 1981.

Сномкку, Noam. Knowledge of Language: Its Nature, Origin, and Use. New York: Praeger, 1986.

Comrie, Bernard. Aspect. Cambridge: Cambridge University Press, 1976.

Costa, Joao, Naama Friedmann. Children Acquire Unaccusatives and A-movement Very Early. Martin Everaert, Marijana Marelj, Tal Siloni (eds.). The Theta System: Argument Structure at the Interface. Oxford Studies in Theoretical Linguistics 37. Oxford: Oxford University Press, 2012, 354-378.

Fisher, Cynthia, David G. Hall, Susan Rakowitz, Lila R. Gleitman. When it is Better to Receive Than to Give: Syntactic and Conceptual Constraints on Vocabulary Growth. Lingua 92 (1994): 333-375.

Gleitman, Lila R. The Structural Sources of Verb Meaning. Language Acquisition 1 (1990): 3-55.

Huttenlocher, Janellen, Patricia Smiley, Rosalind Charney. Emergence of Action Categories in the Child: Evidence from Verb Meanings. Psychological Review 90 (1983): 72-93.

Lee, Joanne N., Letitia R. Naigles. The Input to Verb Learning in Mandarin Chinese: A Role for Syntactic Bootstrapping. Developmental Psychology 41 (2005): 529-540.

Lieven, Elena. Building Language Competence in First Language Acquisition. European Review 16 (2008): 445-456.

Lieven, Elena, Julian Pine, Gillian Baldwin. Lexically-based Learning and Early Grammatical Development. Journal of Child Language 24 (1997): 187-219. 
Lorusso, Paolo, Claudia Caprin, Maria Teresa Guasti. Overt Subject Distribution in Early Italian Children. Alejna Brugos, Manuella R. Clark-Cotton, Seungwan Ha (eds.). A Supplement to the Proceedings of $29^{\text {th }}$ Annual Boston University Conference on Language Development. Somerville: Cascadilla Press, 2005.

MacWhinney, Brian. The Emergence of Language Form Embodiment. Monographs of the Society for Research in Child Development 43 (1978): 1-123.

NinIO, Anat. Model Learning in Syntactic Development: Intransitive Verbs. International Journal of Bilingualism 3 (1999): 111-131.

Pinker, Steven. Language Learnability and Language Development. Cambridge, Mass: Harvard University Press, 1984.

PInker, Steven. Learnability and Cognition: The Acquisition of Argument Structure. Cambridge, MA: MIT Press, 1989.

Reinhart, Tanya, Tal Siloni. The Lexicon-Syntax Parameter: Reflexivization and Other Arity Operations. Linguistic Inquiry 36 (2005): 389-436.

Snyder, William, Nina Hyams, Paola Crisma. Romance Auxiliary Selection with Reflexive Clitics: Evidence of Early Knowledge of Unaccusativity. Eve V. Clark (ed.). The Proceedings of the Twenty-sixth Annual Child Language Research Forum. Stanford, CA: CSLI, 1995.

Snyder, William, Nina Hyams. Children's Passives: The Role of Discourse Features. <https://williamsnyder.uconn.edu/wp-content/uploads/sites/2834/2019/11/Snyder_Hyams_2008.pdf > 26.04. 2021.

Tomasello, Michael. Constructing a Language: A Usage-based Theory of Language Acquisition. Cambridge, MA: Harvard University Press, 2003.

Нина Илић

Сабина Халупка-Решетар

$$
\begin{gathered}
\text { ПРОДУКЦИЈА ГЛАГОЛА У РАЗЛИЧИТИМ ФАЗАМА } \\
\text { УСВАЈАЬА МАТЕРЬЕГ ЈЕЗИКА: ПОДАЦИ ИЗ СРПСКОГ }
\end{gathered}
$$

Р ези и е

Постојећа међујезичка истраживања усвајања глагола са различитом аргументском структуром дају супротстављене закључке. Док се у неким студијама дошло до резултата који говоре у прилог нативистичкој теорији усвајања језика, резултати других истраживања показали су да се усвајање језика, па и глагола, пре може објаснити у оквиру конструктивистичке теорије, где се продукција глагола на раном узрасту заснива на њиховој употреби. Главни циљ овог истраживања био је да испита којим редоследом се усвајају глаголи различите аргументске структуре (неергативни, неакузативни, антикаузативни, транзитивни и дитранзитивни глаголи) у српском језику као матерњем, те да на тај начин допринесе дебати о томе да ли је усвајање језика условљено генетским наслеђем или је оно резултат спољних утицаја (изложености и учења). Тестирано је укупно двадесет глагола, по четири од сваког типа. Укупно смо тестирали осамнаест испитаника, који припадају следећим узрасним групама: 18-21, 23-25, 31-33, 35-38, 39-43 и 48-52 месеци (по троје у свакој групи). Техника прикупљања података је била елицитирана продукција у којој су коришћене играчке и визуелни материјал. Иако је узорак испитаника био мали, забележене су значајне разлике међу групама. Испитаници у најмлађој групи су углавном продуковали транзитивне и неергативне глаголе (код којих постоји каноничка веза између субјекта и агенса), као и неколико неакузативних глагола, али није било дитранзитивних нити антикаузативних глагола. Овај тренд се уочава и у следећој узрасној групи, али су овде испитаници били знатно успешнији у продукцији. Први пут су се јавили дитранзитивни глаголи. Антикаузативни глаголи су се први пут јавили у трећој групи испитаника. Ова група је продуковала готово све неергативне, неакузативне и транзитивне глаголе, али је још увек имала потешкоћа са продукцијом антикаузативних и дитранзитивних глагола. Продукција у наредне три групе је била доста слична, имајући у виду да су испитаници успешно продуковали готово све циљне глаголе, без обзира на њихову врсту. Резултати истраживања указују на то да деца на нижем ступњу развоја језика теже 
продукују глаголе комплексне аргументске структуре (оне код којих је присутан трећи аргумент или оне код којих се одвија комплексан синтаксички деривациони процес). Усвајање глагола почиње усвајањем транзитивних и неергативних глагола, потом се усвајају неакузативни глаголи, док усвајање дитранзитивних и антикаузативних глагола касни. Важно је истаћи да су испитаници адекватно употребљавали морфологију глагола од најранијег узраста, што сведочи о њиховој способности да класификују глаголе као чланове кохерентне синтаксичке категорије, која се разликује од категорије именица, што говори у прилог нативистичкој тези о усвајању језика.

Универзитет у Новом Саду

(Примљено: 5. маја 2021;

Филозофски факултет

прихваћено: 28. октобра 2021)

Одсек за англистику

др Зорана Ђинђића 2, 21000 Нови Сад, Србија

nina.ilic@ff.uns.ac.rs

halupka.resetar@ff.uns.ac.rs 